\title{
Przesłanki restrukturyzacji jako mechanizmu odnowy strategicznej publicznych szkól wyższych
}

\section{Streszczenie}

Jednym z najistotniejszych problemów współczesnych uczelni publicznych jest ich dopasowanie do zmieniających się nieustannie warunków otoczenia. Brak zespolenia tych organizacji z otoczeniem wiąże się ze spadkiem ich efektywności ekonomicznej, co z kolei w świetle obowiązujących regulacji prawnych w dłuższej perspektywie może oznaczać nawet ich likwidację. Dlatego celem opracowania jest rozpoznanie przesłanek przeprowadzenia w publicznych szkołach wyższych restrukturyzacji, która jest jednym z mechanizmów odnowy strategicznej tych organizacji. W opracowaniu analizowano wynik ze sprzedaży, który ustalany jest z uwzględnieniem przychodów i kosztów działalności dydaktycznej, badawczej i wyodrębnionej działalności gospodarczej. Badano także ogólny wynik finansowy uniwersytetów. Ustalono okoliczności opracowywania programu naprawczego prowadzącego do uzyskania równowagi finansowej w uczelniach publicznych. Badane podmioty to funkcjonujące w Polsce uniwersytety. Analizą objęto wyniki finansowe ogółem oraz wyniki ze sprzedaży ustalone w ich sprawozdaniach finansowych za lata 2007-2014. W analizie podstawowego obszaru funkcjonowania uniwersytetów - działalności dydaktycznej i badawczej, ujawniono problem ponoszenia zbyt wysokich kosztów lub osiągania zbyt niskich przychodów. Bez ścisłego nadzoru

Aleksandra Pisarska, Uniwersytet Jana Kochanowskiego w Kielcach, Instytut Zarządzania, ul. Świętokrzyska 21, 25-406 Kielce, e-mail: aleksandra.pisarska@ujk.edu.pl

Jarosław Karpacz, Uniwersytet Jana Kochanowskiego w Kielcach, Instytut Zarządzania, ul. Świętokrzyska 21,25-406 Kielce, e-mail: jaroslaw.karpacz@ujk.edu.pl 
nad poziomem kosztów realizowanych zadań wprowadzenie programu naprawczego może w przyszłości dotyczyć większości publicznych szkół wyższych, jeśli w zakresie ich podstawowej działalności (głównie dydaktycznej) nie będzie równowagi pomiędzy przychodami a kosztami. Pogarszająca się sytuacja finansowa uniwersytetów zmusza ich władze do podjęcia niezbędnych działań korygujących. Celem dalszych badań w tym obszarze będzie wyznaczenie wartości referencyjnych, których osiągnięcie powinno skutkować podjęciem działań na rzecz odnowy strategicznej publicznych uczelni wyższych.

Słowa kluczowe: publiczne szkoły wyższe, odnowa strategiczna, restrukturyzacja, program naprawczy.

Klasyfikacja JEL: I22, I23, I25.

\section{Wprowadzenie}

Współcześnie publiczne szkoły wyższe dość powszechnie odczuwają skutki niedopasowania do zmieniających się warunków otoczenia. Ten utrzymujący się w długim okresie stan pociąga za sobą nie tylko spadek efektywności ekonomicznej, ale wyzwala realną groźbę likwidacji uczelni zgodnie z procedurami zawartymi w rozdziale drugim znowelizowanej Ustawy z dnia 27 lipca 2005 r. Prawo o szkolnictwie wyższym (dalej: UPoSW).

Publiczne szkoły wyższe na bieżąco nie są w stanie ustalić idealnej zbieżności ścieżki swoich zmian strategicznych ze zmianami w otoczeniu, proces zmian jest bowiem dynamiczny i ciągły, tzn. pozbawiony wyraźnego początku i jednoznacznego końca [Quinn 1978]. Dodatkowo na długookresowe zachowania tych organizacji wpływają nie tylko zdarzenia niepewne, lecz także nieznane. Oddziałuje bowiem na nie tak wiele różnych sił i w tak wielu układach, że często nie można przewidywać nawet zdarzeń probabilistycznych. Stąd potrzeba dynamicznego zespolenia czasokresu, kierunku i wielkości zmian strategicznych z czynnikami i uwarunkowaniami występującymi w otoczeniu. Chodzi o to, aby uczelnia przeobrażała się w sposób optymalny, w przeciwnym razie ucierpi jej efektywność. Dlatego też pogarszające się w długim okresie wyniki osiągane przez publiczne szkoły wyższe powinny być dla zarządzających nimi sygnałem do przeprowadzenia odnowy strategicznej, a więc $\mathrm{w}$ istocie ostatnim momentem przerwania pogłębiającego się niedopasowania do otoczenia. Utrzymujący się długotrwale ujemny wynik finansowy (strata ustalana na poziomie ogólnym sprawozdania finansowego) w świetle obowiązującego ustawodawstwa prowadzi uczelnie publiczne w stronę postępowania naprawczego. Jest to jasno określone w przepisach prawa narzędzie, którego zastosowanie ma doprowadzić do szybkiej poprawy wyników finansowych (zwykle przez radykalną obniżkę kosztów lub zwiększenie przychodów uzyskanych ze sprzedaży należących do uczelni nieruchomości). Najczęściej jest ono stosowane doraźnie i bez głębokiej 
przebudowy (reorganizacji) dotyczącej przede wszystkim metod zarządzania tymi złożonymi (z uwagi na wielość zadań, jakie realizują) organizacjami doprowadzi do poprawy jej wyników finansowych na krótki czas. Wdrożenie programu naprawczego, którego realizacja nadzorowana jest przez ministra nauki i szkolnictwa wyższego, nie jest ukierunkowane na zapewnienie zespolenia uczelni z otoczeniem. Nie jest zatem narzędziem odnowy strategicznej, która ma charakter długookresowy (zapewnia zbieżność działalności organizacji z otoczeniem) i kompleksowy (obejmuje wszystkie obszary funkcjonowania organizacji).

Celem opracowania jest rozpoznanie finansowych przesłanek świadczących o potrzebie przeprowadzenia procesu restrukturyzacji publicznej szkoły wyższej jako jednego z możliwych do zastosowania w obecnych warunkach mechanizmów odnowy strategicznej. Poczynione ustalenia będą stanowiły istotny krok na drodze wskazania wartości referencyjnych, przy których zarządzający publicznymi szkołami wyższymi powinni zainicjować proces odnowy strategicznej. Ze względu na dużą złożoność problemu uwaga badawcza zostanie skoncentrowana wyłącznie na rozpoznaniu przesłanek natury finansowej w jednej z grup publicznych uczelni wyższych, jaką stanowią uniwersytety.

\section{Pojęcie i istota odnowy strategicznej organizacji}

W literaturze przedmiotu odnowa strategiczna definiowana jest jako proces, treść i efekt odświeżania lub zmiany tych cech organizacji, które mają znaczący wpływ na perspektywy jej funkcjonowania [Agarwal i Helfat 2009]. Wiąże się ona z dużymi zmianami dla organizacji, jej strategii, struktury [Sharma i Chrisman 1999], dotychczasowych zdolności i/lub koniecznością przegrupowywania (realokacją) jej zasobów [Baden-Fuller i Volberda 1997]. W konsekwencji tak rozumianej odnowy organizacja zmienia się i dopasowuje się do warunków otoczenia [Karpacz 2012]. Odnowa strategiczna obejmuje ona swym zasięgiem całą organizację [Banaszyk i Cyfert 2007]. Nie jest więc wprowadzaniem pojedynczych zmian dostosowawczych, mających na celu dopasowanie się do krótkookresowych fluktuacji i zaburzeń w otoczeniu lub w obrębie organizacji, nie jest też usprawnieniem czy racjonalizacją działań dokonanych jedynie w jakimś obszarze. W przypadku szkół wyższych dotyczy ona przede wszystkim obszarów działalności dydaktycznej i badawczej oraz wszystkich zadań realizowanych w tych obszarach.

Odnowa strategiczna oznacza zasadniczą modyfikację systemu biznesowego i/lub organizacyjnego, której można dokonać przez reorganizację, zmianę technologii, dywersyfikację, przebudowę procesów operacyjnych czy przetasowanie 
portfela produktów (wyrobów i usług) [De Wit i Meyer 2007]. Innymi słowy, odnowa organizacji w perspektywie długookresowej związana jest z przekształceniem kluczowych elementów systemu zarządzania warunkowanych zmianami modelu działania [Bełz 2012].

Ze swej natury odnowa strategiczna ma charakter długookresowy, a więc jak każda zmiana strategiczna ma na celu tworzenie nowej harmonii - nowego typu dopasowania organizacji do warunków zewnętrznych [De Wit i Meyer 2007]. W efekcie procesu odnowy zlikwidowana zostanie luka strategiczna pomiędzy przebiegiem zmian $\mathrm{w}$ organizacji a przebiegiem zmian w otoczeniu. Odnowa strategiczna jest zazwyczaj przeprowadzana w przypadku wykształcenia się luki strategicznej (niedopasowania) albo antycypowania wykształcenia się tejże luki między kompetencjami organizacji a wymaganiami otoczenia [Bratnicki 2000].

W odniesieniu do szkół wyższych otoczenie zgłasza zapotrzebowanie na wysoko wykwalifikowaną kadrę oraz oczekuje innowacyjnych rozwiązań, których aplikacja przyczyni się do zwiększenia efektywności funkcjonowania jego sfery społecznej i gospodarczej. Jednakże w ostatnich latach można zaobserwować zwiększającą się rozbieżność pomiędzy potrzebami otoczenia a efektami działań szkół wyższych. Zminimalizowanie występującego niedopasowania wydaje się niezbędne.

Zastosowanie powyższego podejścia do definiowania istoty odnowy organizacyjnej, wskazujące na konieczność przyjęcia holistycznego podejścia do doskonalenia organizacji, wymusza na zarządzających konieczność realizacji zmian w trzech obszarach organizacji [Cyfert i Krzakiewicz 2015]:

- definicyjnym - określającym pożądany wzorzec rozwoju organizacji, opisywanym z wykorzystaniem koncepcji modelu biznesu i strategicznej karty wyników,

- regulacyjnym - określającym obowiązujące w organizacji standardy i wzorce działań, opisywanym z wykorzystaniem mechanizmów systemu zarządzania,

- realizacyjnym - określającym sposoby wykonywania działań operacyjnych, opisywanym z wykorzystaniem procesów i projektów.

\section{Mechanizmy odnowy strategicznej organizacji}

W literaturze przedmiotu [Banaszyk i Cyfert 2007, Stabryła 2010, Baden-Fuller i Volberda 1997, Karpacz 2011] wyróżnia się cztery mechanizmy (metody) odnowy organizacji:

- reanimację (ożywianie) - rewitalizacja kluczowych kompetencji, co następuje w wyniku uporządkowania albo wykorzystania istniejących zdolności $\mathrm{w}$ procesie uczenia się, 
- przedsięwzięcie - procesy na najwyższym poziomie związane z przenoszeniem kompetencji, włączając tworzenie nowych jednostek i pozbywanie się starych,

- odmłodzenie - program całościowej zmiany, ukierunkowany na rewitalizację organizacji,

- restrukturyzację - ustanawianie nowych reguł i priorytetów oraz definiowanie nowych produktów (wyrobów lub usług).

Zastosowanie każdego ze wskazanych mechanizmów odnowy strategicznej powinno skutkować mniej lub bardziej precyzyjnym dopasowaniem organizacji do warunków otoczenia.

Odnowa obejmuje wiele zmian strategicznych zachodzących w wielu dziedzinach funkcjonowania organizacji. Zmiany te mają na celu dostosowanie organizacji do wymagań otoczenia. Proces odnowy strategicznej może się jednak odbywać rewolucyjnie (kilka odważnych skoków) albo ewolucyjnie (szereg małych kroków) [De Wit i Meyer 2007]. W pierwszym przypadku proces ten przyjmuje postać strumienia modyfikacji tworzywa tego potencjału od danego do innego, zgoła odmiennego jego stanu. W drugim przypadku oznacza proces przeobrażeń, zmian, związany z przechodzeniem do stanów bardziej złożonych, doskonalszych [Czekaj 2010].

Uważa się, że ze względu na wrodzoną niechęć ludzi do zmian żadna daleko idąca zmiana nie może dojść do skutku, jeśli nie pojawią się odpowiednio silne naciski prowadzące do wzrostu napięcia wewnętrznego [De Wit i Meyer 2007]. Przeobrażenia zachodzą więc zwykle nie w sposób miarowy, ale nagły i gwałtowany. Opór ustępuje w jednej chwili, a powstałe napięcie rozładowuje się w krótkim wstrząsie, który powinien być tym silniejszy, im poważniejsza jest zmiana. Ten sposób odnowy strategicznej zapewnia organizacji okresy względnej stabilizacji niezbędnej do właściwego funkcjonowania. Ludzie nie mogą w nieskończoność działać w warunkach wysokiej niepewności i niejednoznaczności, dlatego też odnowa powinna mieć charakter epizodyczny, a nie wielokrotny [De Wit i Meyer 2007]. Z drugiej strony jednak, ciągłe odnawianie organizacji należy uznać za immanentną cechę przedsiębiorczo zarządzanych organizacji, które przekształcają idee w rzeczywiste działania w sposób proaktywny i przezwyciężający ryzyko, bez zwlekania z wykorzystywaniem szans.

W literaturze przedmiotu przyjmuje się, że organizacje mogą najlepiej dopasować się do szans i zagrożeń pojawiających się w ich środowisku zewnętrznym przez wewnętrzną odnowę strategiczną [Nogalski, Karpacz i Wójcik-Karpacz 2015]. U podstaw tego twierdzenia leży szeroka debata na temat tego, czy organizacje mogą samodzielnie odnawiać się w celu utrzymania dynamicznego dopasowania w czasie. Podczas gdy jedni badacze sugerują, że organizacje nie są w stanie się zmieniać, inni wskazują na liczne przykłady długowiecznych orga- 
nizacji, dowodząc, że organizacje są w stanie utrzymać swoją przewagę konkurencyjną w obliczu zmian przez odnowę strategiczną [Ben-Menahem i in. 2013].

Przyjmując perspektywę adaptacji, można stwierdzić, że odnowa strategiczna może zostać osiągnięta przez intencjonalne zarządzanie zmianami, a głównym zadaniem menedżerów jest wyzwolenie zdolności do absorpcji nowej wiedzy. Łącząc perspektywy selekcji i adaptacji otoczenia, stwierdzono, że ciągła odnowa strategiczna wymaga, aby szybkość działań odnowy strategicznej była dostosowana przez cały czas do tempa zmian w otoczeniu zewnętrznym [Karpacz 2011]. Ten ważny wymiar odnowy strategicznej nie jest jednak dostatecznie zbadany [Nogalski, Karpacz i Wójcik-Karpacz 2015].

W świetle powyższych rozważań intrygujące jest rozpoznanie potrzeby wkroczenia publicznych uczelni na ścieżkę zmian strategicznych prowadzącą do ich strategicznej odnowy, która może zabezpieczyć je przed sytuacją, w której nie będą mogły sprostać wymaganiom stawianym przez otoczenie. Za okoliczność skłaniającą do przeprowadzenia odnowy strategicznej publicznych uczelni uznano pogarszające się wyniki finansowe ustalane w sformalizowanych rachunkach zysków i strat, w których wykazywane są wyniki finansowe osiągane (przez organizacje objęte obowiązkiem sporządzania sprawozdań finansowych) w różnego rodzaju działalności (operacyjnej: dydaktycznej, badawczej i wyodrębnionej działalności gospodarczej, oraz pozostałej: pozostałej działalności operacyjnej, finansowej i ze zdarzeń nadzwyczajnych) zgodnie z ustawą prawo o szkolnictwie wyższym oraz ustawą o rachunkowości (UoR). Jednocześnie należy pamiętać, że odnowa strategiczna organizacji wiąże się z natury z niepewnymi rezultatami, ponieważ często jej realizacja wymaga rezygnacji ze znacznie pewniejszych korzyści, wynikających z posiadanych kompetencji [Argawal i Helfat 2009].

Podsumowując ten fragment rozważań, można stwierdzić, że uwarunkowania kontekstualne (tworzone głównie przez obowiązujące przepisy prawa regulującego działalność publicznych uczelni) popychają zarządzających publicznymi szkołami wyższymi w kierunku odnowy strategicznej tych organizacji przez restrukturyzację naprawczą, przy czym podstawą jej zainicjowania są pogarszające się wyniki finansowe tych podmiotów.

\section{Wyniki finansowe jako przesłanka podejmowania odnowy strategicznej uczelni}

W opracowaniu poddano analizie wynik ze sprzedaży, który ustalony jest przy uwzględnieniu przychodów i kosztów działalności dydaktycznej, badawczej i wyodrębnionej działalności gospodarczej. Badano także ogólny wynik finan- 
sowy netto uniwersytetów (jako wymierny efekt funkcjonowania organizacji), obejmujący wynik ze sprzedaży skorygowany o przychody i koszty pozostałej działalności operacyjnej, działalności tych organizacji na rynkach finansowych oraz zysków i strat nadzwyczajnych. Pogłębiona analiza wyników finansowych uniwersytetów zostanie dokonana $\mathrm{z}$ uwzględnieniem kluczowych zasad obowiązujących jednostki sektora finansów publicznych (a takimi są uczelnie) wyrażających się w szczególnej trosce o mienie i finanse publiczne. Obserwacja działań operacyjnych uczelni pozwoli na stopniowe doprowadzenie ich finansów do koniecznej równowagi i optymalnego wykorzystania ich zasobów.

Ustalono także okoliczności opracowywania programu naprawczego prowadzącego do uzyskania równowagi finansowej w uczelniach publicznych. Badane podmioty to uniwersytety funkcjonujące $\mathrm{w}$ Polsce finansowane ze środków MNiSW. Badaniami objęto wyniki finansowe ogółem oraz wyniki ze sprzedaży ustalone w sprawozdaniach finansowych za lata 2007-2014. W Polsce realizuje swoje zadania 18 uniwersytetów, które należą do sektora publicznego; działają one w oparciu o ustawę prawo o szkolnictwie wyższym. Działalność uniwersytetów (jednostek sektora finansów publicznych) jest finansowana $\mathrm{z}$ dotacji z budżetu państwa na zadania ustawowo określone oraz może być finansowana z przychodów własnych (art. $92 \mathrm{UPoSW}$ ).

W przedstawionej analizie wykorzystano dane pochodzące ze sprawozdań finansowych uniwersytetów za lata 2007-2014 zawarte w zasobach „Monitora Polskiego B” (lata 2007-2011) oraz „Monitora Sądowego i Gospodarczego” (lata 2012-2014). Wzięto w niej pod uwagę następujące uniwersytety: Uniwersytet w Białymstoku (UwB), Uniwersytet Kazimierza Wielkiego (UKW), Uniwersytet Gdański (UG), Uniwersytet Śląski (UŚ), Uniwersytet Jana Kochanowskiego (UJK), Uniwersytet Jagielloński (UJ), Uniwersytet Marii Curie-Skłodowskiej (UMCS), Uniwersytet Łódzki (UŁ), Uniwersytet Warmińsko-Mazurski (UWM), Uniwersytet Opolski (UO), Uniwersytet im. Adama Mickiewicza (UAM), Uniwersytet Rzeszowski (UR), Uniwersytet Szczeciński (US), Uniwersytet Mikołaja Kopernika (UMK), Uniwersytet Warszawski (UW), Uniwersytet Kardynała Stefana Wyszyńskiego (UKSW), Uniwersytet Wrocławski (UWr) i Uniwersytet Zielonogórski (UZ).

Zmieniające się warunki funkcjonowania szkół wyższych dotyczące zmniejszającej się liczby studentów powodują konieczność zmian w zakresie gospodarowania ich zasobami, a także zmian w obszarze organizacji i zarządzania. Zmiany te w sposób bezpośredni wpływają na zmniejszanie się zasobów środków pieniężnych, którymi jednostki te mogą dysponować. Sytuacja majątkowo-finansowa związana ze zmniejszaniem się przychodów może doprowadzić do wystąpienia nadwyżki kosztów nad przychodami, czyli straty. Przedłużanie się sytuacji, w której szkoły wyższe ustalają w sprawozdaniach finansowych 
ujemne wyniki finansowe, powodują, że konieczne stają się działania naprawcze. W ściśle określonych sytuacjach (ustalonych w Rozporządzeniu Ministra Nauki i Szkolnictwa Wyższego z dnia 5 października 2011 r. w sprawie zakresu i trybu realizacji programu naprawczego prowadzącego do uzyskania równowagi finansowej uczelni publicznej) zarządzający publicznymi szkołami wyższymi mają obowiązek wprowadzić działania na podstawie programu naprawczego. Program naprawczy ma w radykalny sposób przebudować gospodarkę majątkową i finansową jednostki. Czas na dokonanie restrukturyzacji naprawczej jest zwykle stosunkowo krótki ze względu na narastający deficyt, który jest najczęściej finansowany $z$ kredytów bankowych, a to powoduje przede wszystkim dodatkowe koszty.

Pogarszające się wyniki finansowe publicznych szkół wyższych w świetle obowiązującego ustawodawstwa kierują je w stronę postępowania naprawczego. Aby go uniknąć, uczelnia może odpowiednio wcześniej reagować na zmiany otoczenia, dokonując odnowy strategicznej.

Warto zwrócić uwagę, że perspektywa likwidacji uczelni publicznej jest największym, ale nie jedynym zagrożeniem związanym z jej niewłaściwym dopasowaniem do warunków otoczenia. Innym jest jej dopasowanie tylko w stopniu reaktywnym, niepozwalającym na pełne wykorzystanie szans. Otwartość na takie wyzwania wiąże się z umiejętnością wychodzenia decydentów publicznych szkół wyższych poza utarte schematy, wykraczania poza dotychczasową kulturę organizacyjną.

Tabela 1 prezentuje przychody, koszty i wynik finansowy uniwersytetów za lata 2007-2014. W większości analizowanych okresów stwierdzono nadwyżkę przychodów nad kosztami. Ustalono również, że w żadnym z badanych lat nie zdarzyło się, by wszystkie uniwersytety osiągnęły dodatni wynik finansowy. Zsumowane przychody i koszty uniwersytetów w latach 2007-2014 przedstawiają nadwyżkę przychodów nad kosztami (razem), wyjątkiem jest 2012 r., w którym ustalony (zsumowany) wynik finansowy wszystkich uniwersytetów był stratą i wynosił -27 696,94 mln zł.

Najwyższą stratę odnotowały w 2012 r. Uniwersytet Szczeciński-22 096,45 mln zł, Uniwersytet Kardynała Stefana Wyszyńskiego -11 650,77 mln zł oraz Uniwersytet Jana Kochanowskiego -10 511,24 mln zł. W 2012 r. stratę stwierdzono aż w 10 uniwersytetach, w tym roku zaczęło też obowiązywać rozporządzenie ministra nauki i szkolnictwa wyższego dotyczące konieczności sporządzania programów naprawczych.

Uniwersytetami, w których nie stwierdzono straty ogółem w badanym okresie, były: Uniwersytet Śląski, Uniwersytet Jagielloński, Uniwersytet Rzeszowski i Uniwersytet Wrocławski (tabela 2). 


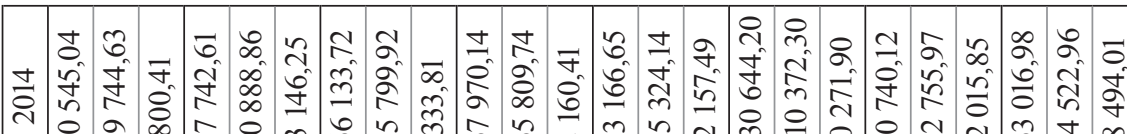

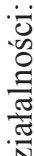

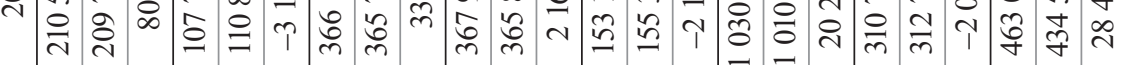

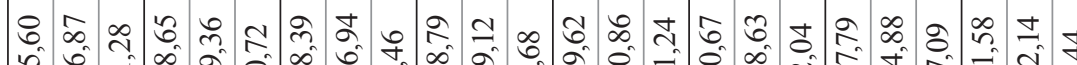

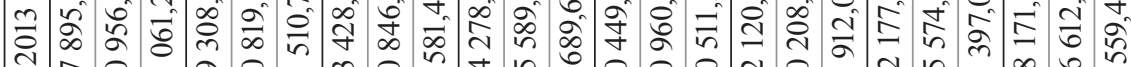

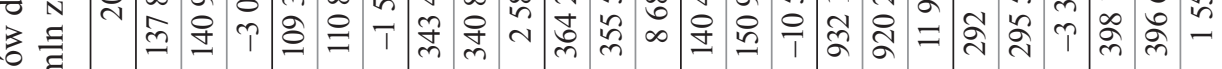

을

तै

웅

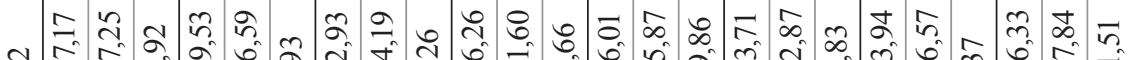

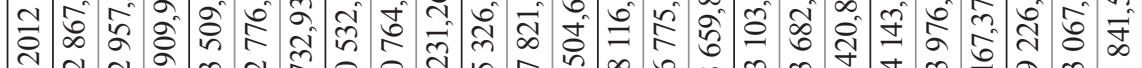
先 으응

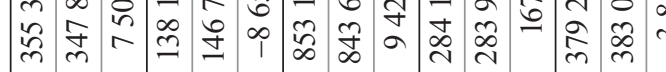

ह

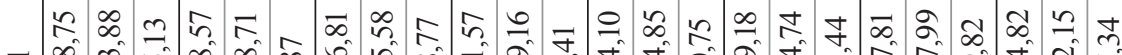

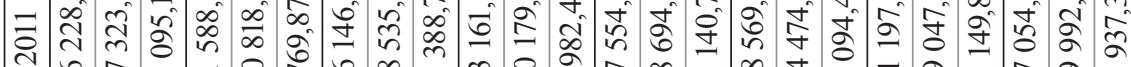
กิ

总 :

岤

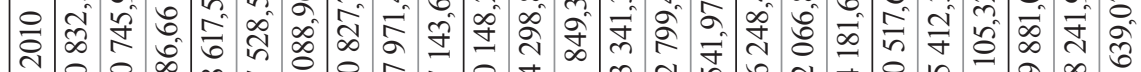

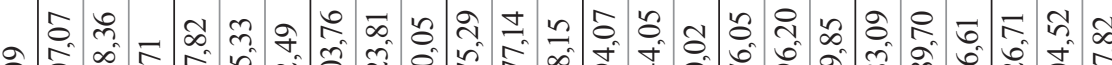

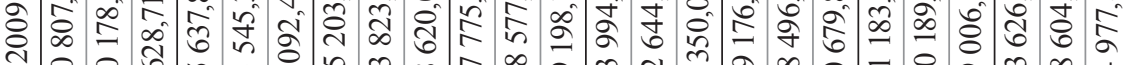
๙ू

N

으 이

究要

तิ

궁

등

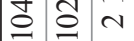
के

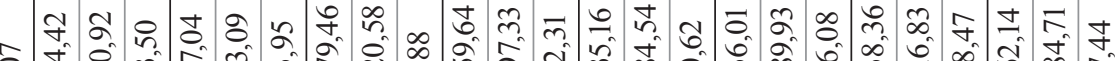

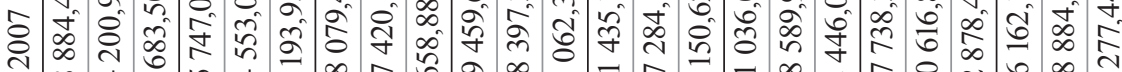

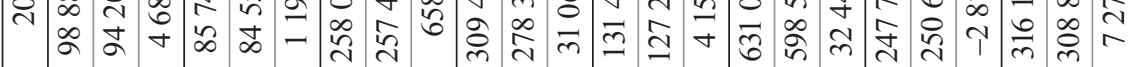

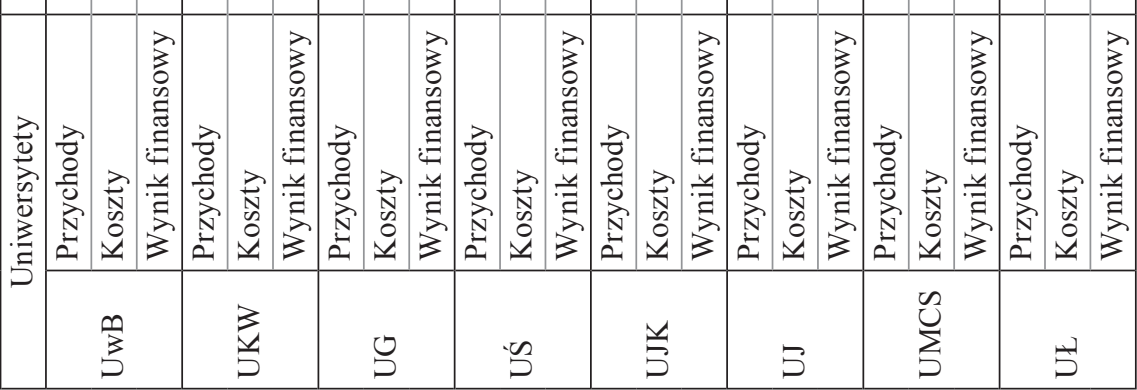




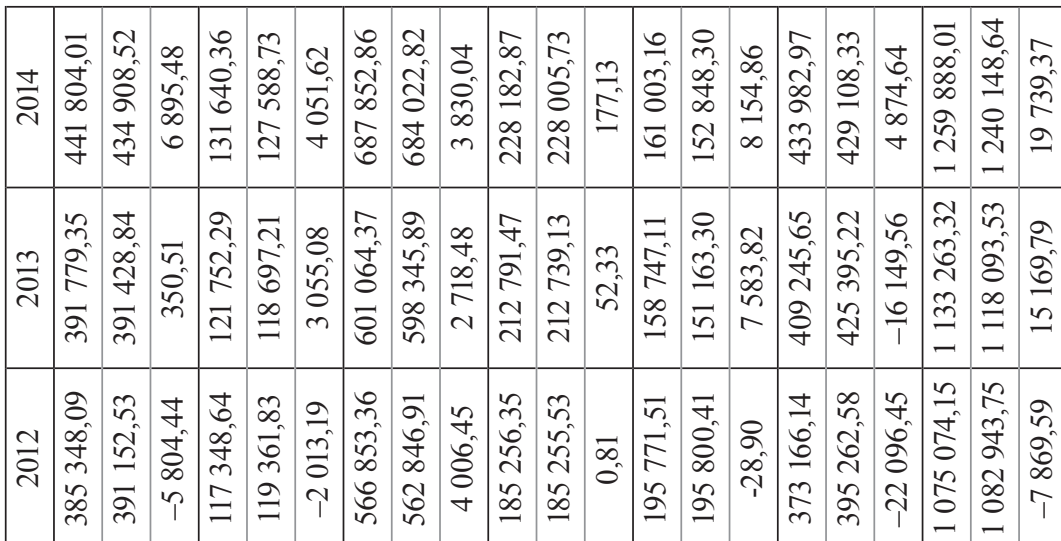
そิ

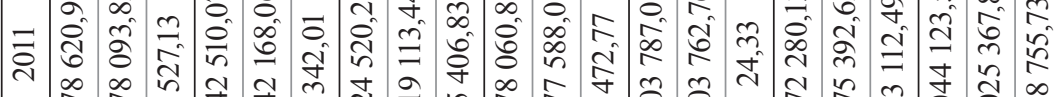

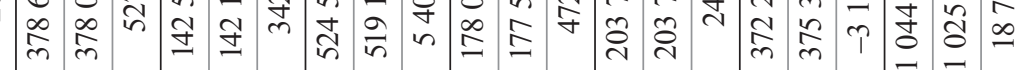

gे

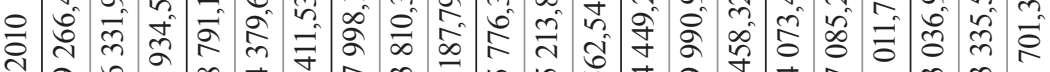

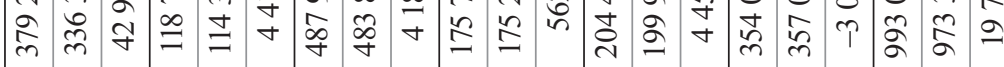

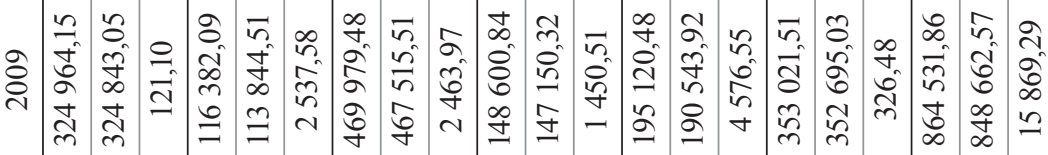

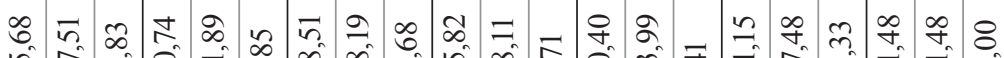
完会

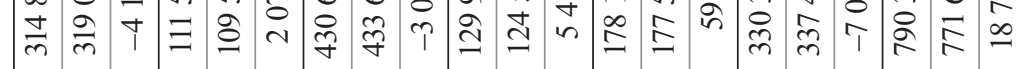

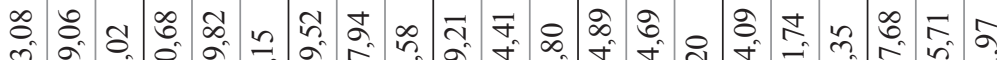

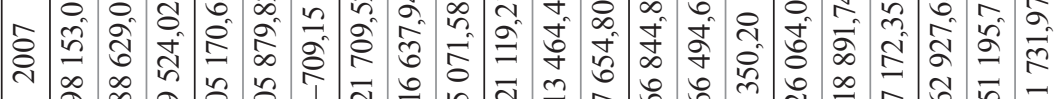

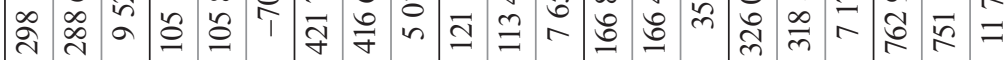

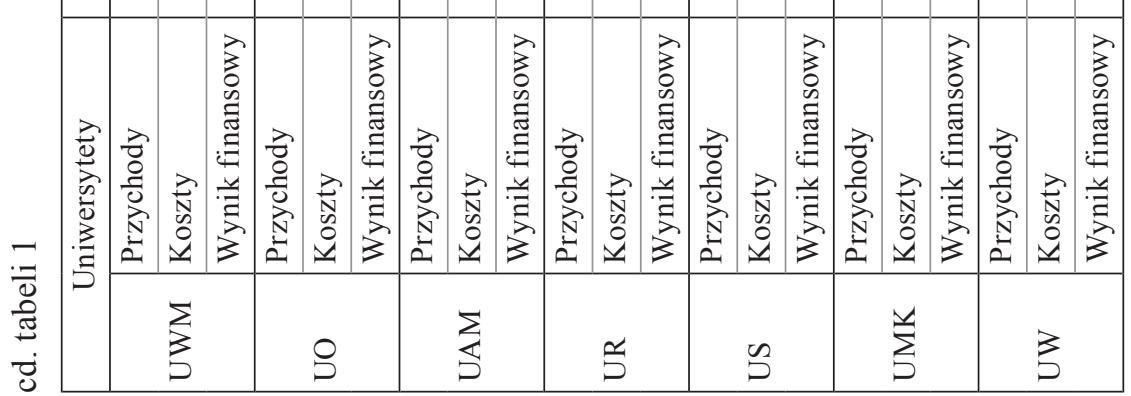




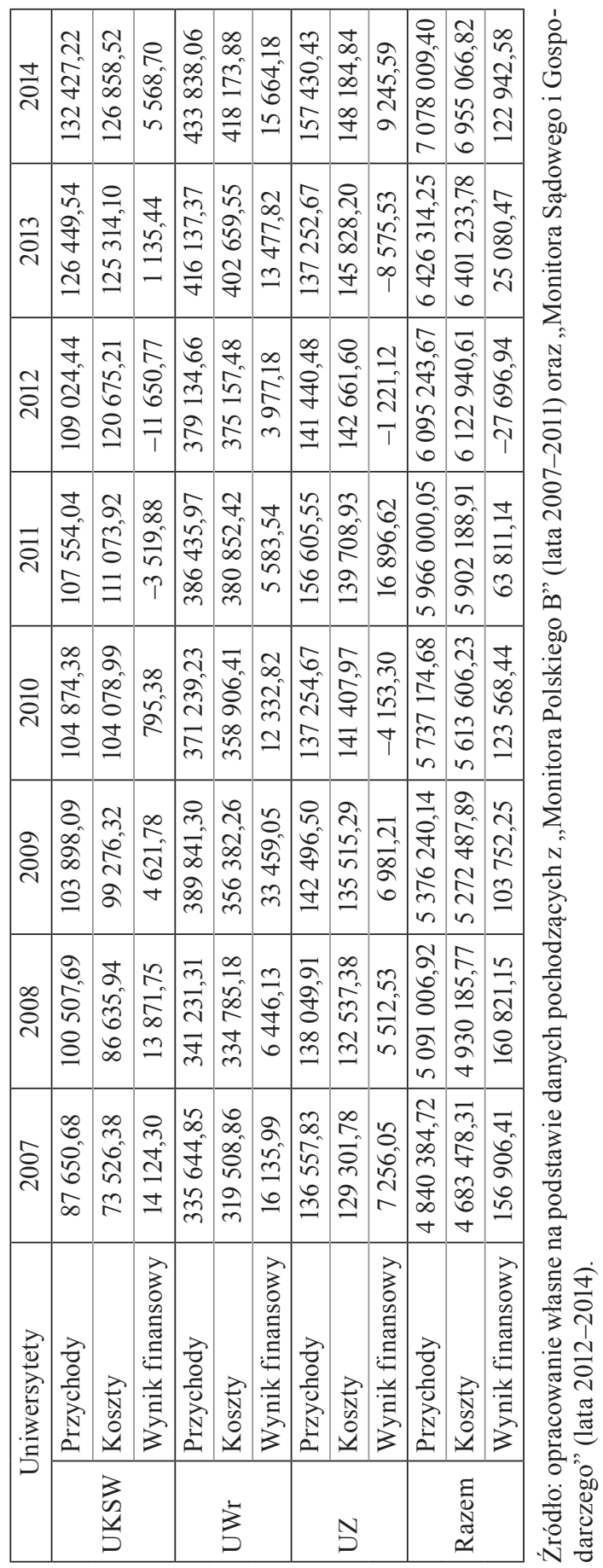


Największą liczbę uniwersytetów, w których sprawozdaniach finansowych wykazano stratę, odnotowano w 2012 r. (10 organizacji), natomiast najmniejszą ich liczbę w 2007 r. (2 organizacje). Przychody ogółem (z uwzględnieniem przychodów/zysków: ze sprzedaży, pozostałej działalności operacyjnej oraz finansowej i zdarzeń nadzwyczajnych) w badanym okresie wykazywały tendencję rosnącą. W większości uniwersytetów była to tendencja jednolita (tabela 2), wyjątkami były: Uniwersytet Kazimierza Wielkiego (w 2014 r.), Uniwersytet Śląski (w latach 2009 i 2011), Uniwersytet Jana Kochanowskiego (w latach 2008 i 2012), Uniwersytet Opolski (w 2011 r.), Uniwersytet Szczeciński (w latach 2011-2013), Uniwersytet Wrocławski (w latach 2010 i 2012) oraz Uniwersytet Zielonogórski (w latach 2010, 2012 i 2013).

Koszty ogółem (koszty/straty nadzwyczajne) związane ze sprzedażą, pozostałą działalnością operacyjną oraz finansową i zdarzeniami nadzwyczajnymi w badanym okresie wykazywały tendencję rosnącą (tabela 1). W większości uniwersytetów była to tendencja jednolita, wyjątkami były: Uniwersytet Jana Kochanowskiego (w 2012 r.), Uniwersytet Marii Curie-Skłodowskiej (w 2009 r.), Uniwersytet Opolski (w latach 2011 i 2012), Uniwersytet Szczeciński (w latach 2012 i 2013), Uniwersytet Wrocławski (w 2012 r.) oraz Uniwersytet Zielonogórski (w 2011 r.).

Ogólny wynik finansowy w uniwersytetach (wynik finansowy netto) podlega ocenie w związku regulacjami prawnymi dotyczącymi obowiązku wprowadzania programu naprawczego. Wynik finansowy netto obejmuje wszystkie obszary działalności uczelni. Jego analiza w większości badanych jednostek organizacyjnych wykazała wartość dodatnią. Należy jednak zauważyć, że tylko analiza poszczególnych obszarów ustalanego wyniku finansowego pozwala prawidłowo ocenić ryzyko funkcjonowania tych jednostek i zobowiązuje władze uczelni do podjęcia działań naprawczych. Działania te mają prowadzić do uzyskania równowagi finansowej przez szkoły wyższe i do uniknięcia sytuacji, w której konieczne będzie wprowadzenie programu naprawczego nadzorowanego przez ministra nauki i szkolnictwa wyższego.

W tabeli 2 przedstawiono wartości przychodów, kosztów oraz wyniku finansowego w zakresie działalności operacyjnej (dydaktycznej, badawczej i wyodrębnionej działalności gospodarczej). Działalność operacyjna (ze szczególnym uwzględnieniem działalności dydaktycznej) jako podstawowy obszar działania uniwersytetów powinna być objęta szczególnym nadzorem władz uczelni. Należy w tym celu wykorzystać właściwe narzędzia służące do oceny bieżącej i przyszłej sytuacji ekonomicznej organizacji sektora publicznego, stosowane w planowaniu działań uczelni. Szczególny nacisk powinien być położony na uzyskanie najlepszego efektu przy ograniczonych zasobach, jakimi gospodarują (zarządzają) władze uniwersytetów. 
Najwyższe wartości straty ze sprzedaży odnotowano w przypadku Uniwersytetu Warszawskiego $-53141,27 \mathrm{mln}$ zł w 2014 r. oraz $-40311,45 \mathrm{mln}$ zł w 2011 r., Uniwersytetu im. Adama Mickiewicza w 2013 r. -50 233,45 mln zł oraz $-43994,88 \mathrm{mln}$ zł w $2014 \mathrm{r}$.

W 2012 r. stratę ze sprzedaży stwierdzono aż w 17, w 2013 r. w 16, a w 2014 r. w 15 uniwersytetach. W latach 2007-2014 nie było uniwersytetu, w którym nie wystąpiła strata ze sprzedaży (podstawowym obszarze działania, w którym realizowane są ich zadania).

W czterech uniwersytetach (Uniwersytet Gdański, Uniwersytet im. Adama Mickiewicza, Uniwersytet Mikołaja Kopernika i Uniwersytet Warszawski) odnotowano stratę ze sprzedaży we wszystkich badanych latach (8 okresów). Największą liczbę okresów sprawozdawczych, w których stwierdzono stratę ze sprzedaży odnotowano w przypadku Uniwersytetu Marii Curie-Skłodowskiej, Uniwersytetu Łódzkiego i Uniwersytetu Warmińsko-Mazurskiego (7 okresów) oraz Uniwersytetu w Białymstoku, Uniwersytetu Jana Kochanowskiego i Uniwersytetu Rzeszowskiego (6 okresów).

Najmniejszą liczbę okresów sprawozdawczych, w których stwierdzono stratę ze sprzedaży, odnotowano w przypadku Uniwersytetu Jagiellońskiego i Uniwersytetu Kardynała Stefana Wyszyńskiego (2 okresy) oraz Uniwersytetu Wrocławskiego (3 okresy). Największą liczbę uniwersytetów, w których sprawozdaniach finansowych wystąpiła strata ze sprzedaży, stwierdzono w latach 2012 (17 organizacji), 2013 (16 organizacji) i 2014 (15 organizacji), natomiast najmniejszą ich liczbę w 2007 r. (8 organizacji).

Przychody ze sprzedaży w badanym okresie (2007-2014) wykazywały tendencję rosnącą we wszystkich badanych organizacjach. W większości uniwersytetów była to jednak tendencja niejednolita; wyjątkami były: Uniwersytet Jagielloński, Uniwersytet Warmińsko-Mazurski, Uniwersytet im. Adama Mickiewicza, Uniwersytet Rzeszowski, Uniwersytet Mikołaja Kopernika, Uniwersytet Warszawski i Uniwersytet Kardynała Stefana Wyszyńskiego.

Koszty poniesione na działalność operacyjną (ściśle związane ze sprzedażą) w badanym okresie wykazywały tendencję rosnącą. W większości uniwersytetów była to jednak tendencja niejednolita (podobnie jak w przypadku przychodów). Wyjątkami były: Uniwersytet Śląski, Uniwersytet Jagielloński, Uniwersytet Łódzki, Uniwersytet Warmińsko-Mazurski, Uniwersytet im. Adama Mickiewicza, Uniwersytet Rzeszowski, Uniwersytet Mikołaja Kopernika i Uniwersytet Warszawski.

Zsumowane wyniki ze sprzedaży (tabela 2) badanych uniwersytetów wykazują stratę w 7 na 8 analizowanych okresów sprawozdawczych (w latach 2008-2014). Ustalone wyniki ze sprzedaży miały jednolitą tendencję rosnącą (z wyjątkiem 2014 r.), od zysku w 2007 r. w wysokości 9275,26 mln zł, do straty w wysokości 


\begin{tabular}{|c|c|c|c|c|c|c|c|c|c|c|c|c|c|c|c|c|c|c|c|c|c|}
\hline$\stackrel{Ð}{\stackrel{\overbrace{}}{~}}$ & 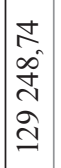 & $\begin{array}{l}n \\
m \\
\tilde{f} \\
\tilde{f} \\
m \\
m\end{array}$ & \begin{tabular}{l}
$\vec{\vdots}$ \\
$\underset{J}{J}$ \\
\multirow{T}{*}{}
\end{tabular} & $\begin{array}{l}\infty \\
\alpha \\
\tilde{n} \\
\tilde{n} \\
\alpha \\
\alpha\end{array}$ & $\begin{array}{l}\widetilde{O} \\
0 \\
0 \\
0 \\
N \\
\tilde{O} \\
0\end{array}$ & $\begin{array}{c}t \\
0 \\
i \\
0 \\
0 \\
0 \\
1\end{array}$ & 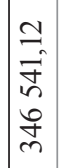 & 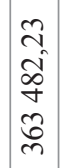 & $\begin{array}{l}= \\
\vec{y} \\
2 \\
0 \\
1\end{array}$ & 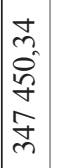 & $\begin{array}{l}0 \\
+ \\
d \\
a \\
d \\
d \\
d\end{array}$ & 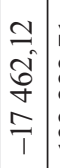 & $\begin{array}{l}\vec{N} \\
\tilde{N} \\
\tilde{N} \\
\tilde{n} \\
\tilde{n}\end{array}$ & 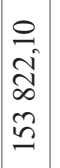 & $\begin{array}{l}2 \\
\hat{2} \\
2 \\
\hat{n} \\
\vec{\tau}\end{array}$ & 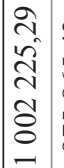 & $\begin{array}{l}\mathfrak{r} \\
\mathfrak{b} \\
\infty \\
\mathfrak{n} \\
\hat{a}\end{array}$ & $\begin{array}{l}n \\
\infty \\
0 \\
2 \\
\infty \\
b \\
2\end{array}$ & $\begin{array}{l}n \\
\tilde{2} \\
\hat{2} \\
\infty \\
0 \\
0\end{array}$ & 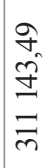 & 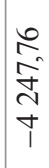 \\
\hline 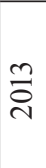 & $\begin{array}{l}\bar{\sigma} \\
\hat{0} \\
\delta \\
\delta \\
o \\
\text { d. }\end{array}$ & $\begin{array}{l}\hat{o} \\
\tilde{o} \\
\tilde{\rho} \\
\tilde{m} \\
\tilde{2}\end{array}$ & $\begin{array}{l}\simeq \\
2 \\
2 \\
\approx \\
1\end{array}$ & $\begin{array}{l}\hat{f} \\
\tilde{\sigma} \\
\alpha \\
\tilde{a}\end{array}$ & $\begin{array}{l}0 \\
\tilde{2} \\
\hat{2} \\
\hat{\alpha} \\
\tilde{0}\end{array}$ & $\begin{array}{l}2 \\
\infty \\
\infty \\
2 \\
\hat{i}\end{array}$ & $\mid \begin{array}{l}\infty \\
\infty \\
\Xi \\
\Xi \\
\bar{\Xi} \\
\bar{m}\end{array}$ & $\begin{array}{l}\tilde{\infty} \\
\hat{0} \\
n \\
\tilde{n} \\
\hat{n}\end{array}$ & $\begin{array}{l}\hat{a} \\
\dot{J} \\
0 \\
0 \\
\hat{1}\end{array}$ & $\begin{array}{l}0 \\
0 \\
\tilde{N} \\
\infty \\
0 \\
\infty \\
m\end{array}$ & 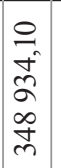 & $\begin{array}{c}8 \\
0 \\
\infty \\
\infty \\
\infty \\
\infty \\
1\end{array}$ & 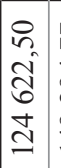 & 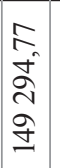 & 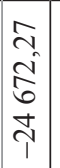 & 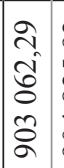 & 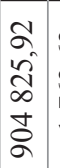 & 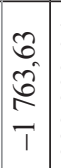 & 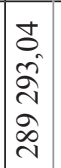 & 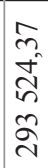 & $\vec{y}$ \\
\hline$\stackrel{\stackrel{\sim}{\check{~}}}{\sim}$ & $\begin{array}{l}n \\
n \\
\tilde{N} \\
\tilde{N} \\
\tilde{n}\end{array} \mid$ & $\begin{array}{l}\tilde{n} \\
\tilde{n} \\
n \\
\tilde{n} \\
n\end{array}$ & $\begin{array}{l}2 \\
2 \\
\delta \\
i \\
\hat{T}\end{array}$ & $\begin{array}{l}0 \\
\simeq 1 \\
0 \\
\infty\end{array}$ & $\begin{array}{l}N \\
\tilde{o} \\
\dot{J} \\
a \\
\tilde{\sigma}\end{array}$ & $\begin{array}{l}2 \\
2 \\
\infty \\
0 \\
\delta \\
+ \\
1\end{array}$ & $\begin{array}{l}= \\
a \\
\dot{a} \\
\hat{0} \\
\grave{2} \\
2\end{array}$ & $\begin{array}{l}0 \\
n \\
\tilde{n} \\
\tilde{f} \\
n \\
\tilde{n}\end{array}$ & 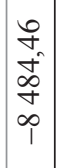 & $\begin{array}{l}\stackrel{0}{b} \\
\vec{a} \\
\dot{b} \\
m \\
m \\
m\end{array}$ & 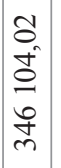 & $\begin{array}{l}\mathcal{J} \\
\mathcal{J} \\
\exists \\
\mathcal{J} \\
\mathcal{T}\end{array}$ & 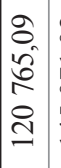 & 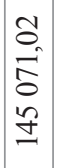 & 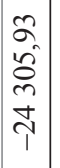 & $\begin{array}{c}\infty \\
\tilde{N} \\
\tilde{\delta} \\
0 \\
\tilde{N} \\
\infty \\
\infty\end{array}$ & $\begin{array}{l}\stackrel{m}{\sim} \\
\infty \\
\stackrel{\infty}{r} \\
\infty \\
\infty \\
\infty\end{array}$ & $\begin{array}{l}n \\
\tilde{2} \\
\tilde{D} \\
\tilde{m} \\
\tilde{n}\end{array}$ & $\begin{array}{l}\hat{n} \\
\hat{2} \\
\hat{2} \\
\hat{2} \\
\hat{v}\end{array}$ & 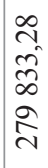 & $\begin{array}{l}\bar{\sigma} \\
\infty \\
\hat{N} \\
\uparrow\end{array}$ \\
\hline$\overline{\vec{\sigma}}$ & 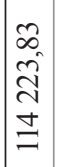 & 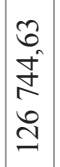 & $\begin{array}{l}8 \\
\infty \\
\tilde{N} \\
\simeq \\
\nearrow\end{array}$ & 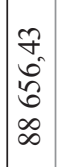 & $\begin{array}{l}I \\
\overrightarrow{0} \\
\infty \\
\infty \\
\infty\end{array}$ & $\begin{array}{l}n \\
\stackrel{0}{0} \\
\stackrel{\tau}{1}\end{array}$ & $\begin{array}{l}\exists \\
\tilde{n} \\
\tilde{n} \\
\tilde{n} \\
\tilde{v}\end{array}$ & 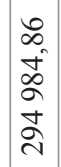 & $\begin{array}{l}n \\
\hat{\alpha} \\
g \\
= \\
=\end{array}$ & 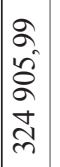 & $\begin{array}{l}2 \\
\tilde{n} \\
n \\
\infty \\
\infty \\
m\end{array}$ & 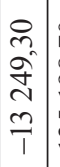 & $\begin{array}{l}\stackrel{2}{\infty} \\
\infty \\
\stackrel{\infty}{n} \\
\ddot{n}\end{array}$ & $\begin{array}{l}\Xi \\
\infty \\
\tilde{N} \\
\tilde{I}\end{array}$ & $\begin{array}{l}0 \\
+ \\
0 \\
0 \\
0 \\
\ddots 1 \\
T\end{array}$ & $\begin{array}{l}2 \\
2 \\
\tilde{N} \\
2 \\
2 \\
2\end{array}$ & $\begin{array}{l}2 \\
N \\
\tilde{N} \\
0 \\
0 \\
\infty \\
0 \\
\end{array}$ & $\frac{n}{n}$ & 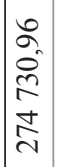 & 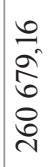 & $\begin{array}{l}\curvearrowright \\
\infty \\
\vdots \\
\pm \\
\pm\end{array}$ \\
\hline$\stackrel{\circ}{\stackrel{ }{ }}$ & $\begin{array}{l}\vec{n} \\
2 \\
2 \\
2 \\
\varrho \\
=\end{array}$ & 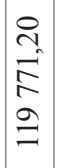 & $\begin{array}{l}\frac{a}{\sigma} \\
\hat{\infty} \\
\stackrel{\infty}{1}\end{array}$ & $\begin{array}{l}\hat{f} \\
\mathscr{8} \\
\infty \\
\infty \\
\infty \\
\infty\end{array}$ & $\begin{array}{l}尺 \\
\infty \\
\infty \\
\infty \\
\infty \\
\infty\end{array}$ & 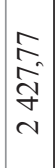 & $\begin{array}{l}\tilde{N} \\
\tilde{\infty} \\
\infty \\
\sim \\
\tilde{\infty} \\
\tilde{N}\end{array}$ & 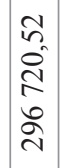 & 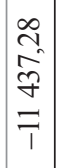 & 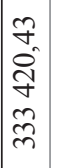 & 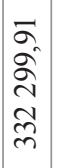 & $\begin{array}{l}\vec{n} \\
\tilde{\Omega} \\
\beth \\
=\end{array}$ & $\mid \begin{array}{l}0 \\
n \\
\infty \\
\infty \\
0 \\
n \\
n \\
n\end{array}$ & $\begin{array}{l}0 \\
\tilde{n} \\
\infty \\
\hat{0} \\
\dot{ \pm}\end{array}$ & 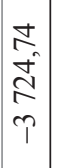 & 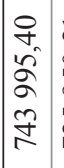 & $\begin{array}{l}\vec{n} \\
\hat{n} \\
2 \\
n \\
\hat{N}\end{array}$ & $\begin{array}{l}9 \\
\mathfrak{v} \\
0 \\
\infty \\
-1\end{array}$ & $\begin{array}{l}m \\
\stackrel{n}{f} \\
n \\
n \\
n \\
\sim\end{array}$ & 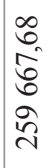 & 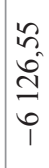 \\
\hline ஓे & 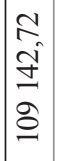 & $\begin{array}{l}n \\
n \\
n \\
6 \\
2 \\
0\end{array}$ & $\begin{array}{l}\vec{\infty} \\
\tilde{N} \\
\tilde{1}\end{array}$ & $\begin{array}{l}\hat{f} \\
\delta \\
\tilde{\sigma} \\
\tilde{\sigma} \\
\hat{\infty}\end{array}$ & $\begin{array}{l}\infty \\
\infty \\
0 \\
i \\
n \\
\infty\end{array}$ & $\begin{array}{l}2 \\
2 \\
2 \\
\sigma \\
-\end{array}$ & 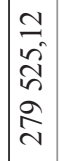 & 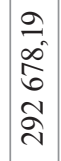 & $\begin{array}{c}\infty \\
0 \\
n \\
n \\
n \\
\cdots \\
1\end{array}$ & $\begin{array}{l}n \\
\infty \\
0 \\
0 \\
0 \\
m \\
m\end{array}$ & 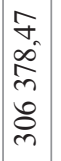 & $\begin{array}{c}\infty \\
\infty \\
\infty \\
\infty \\
\infty \\
0\end{array}$ & 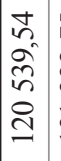 & $\begin{array}{l}\stackrel{n}{a} \\
\tilde{N} \\
\tilde{n} \\
\tilde{n}\end{array}$ & $\begin{array}{l}\vec{\sim} \\
\hat{\infty} \\
\infty \\
\hat{\infty} \\
\frac{1}{1}\end{array}$ & 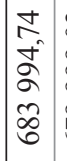 & $\begin{array}{l}2 \\
2 \\
2 \\
2 \\
2 \\
\hat{\sigma}\end{array}$ & $\begin{array}{l}\vec{n} \\
\hat{n} \\
2 \\
m\end{array}$ & 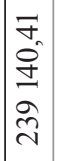 & 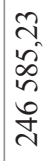 & \begin{tabular}{l}
$O$ \\
$\infty$ \\
\multirow{J}{+}{} \\
$\uparrow$
\end{tabular} \\
\hline$\stackrel{\infty}{\stackrel{2}{\circ}}$ & $\begin{array}{l}\hat{f} \\
\tilde{\delta} \\
\stackrel{n}{\alpha} \\
\overrightarrow{0}\end{array}$ & 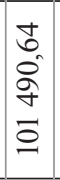 & 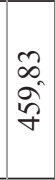 & $\begin{array}{l}\vec{\sigma} \\
\tilde{\infty} \\
\infty \\
\tilde{\alpha} \\
\infty\end{array}$ & $\begin{array}{l}n \\
\tilde{\delta} \\
\infty \\
0 \\
0 \\
\infty\end{array}$ & $\begin{array}{c}\vec{n} \\
\tilde{\delta} \\
\frac{1}{1}\end{array}$ & 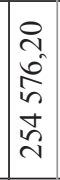 & 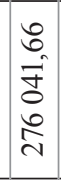 & $\begin{array}{l}0 \\
+ \\
\tilde{\sigma} \\
+ \\
\vec{\tau} \\
\overrightarrow{1}\end{array}$ & $\begin{array}{l}\vec{n} \\
\tilde{2} \\
\hat{m} \\
\hat{2} \\
\hat{\lambda}\end{array}$ & $\begin{array}{l}2 \\
\stackrel{2}{1} \\
\hat{n} \\
2 \\
2 \\
2\end{array}$ & 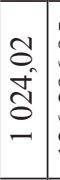 & 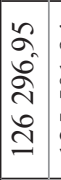 & 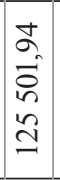 & $\begin{array}{l}5 \\
2 \\
2\end{array}$ & 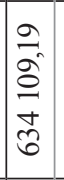 & $\begin{array}{l}\vec{\infty} \\
\infty \\
\tilde{2} \\
\hat{\sigma} \\
\sigma\end{array}$ & $\begin{array}{c}\infty \\
2 \\
2 \\
\stackrel{2}{J} \\
\pm\end{array}$ & 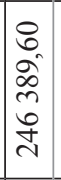 & 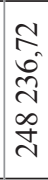 & 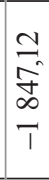 \\
\hline 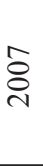 & $\begin{array}{l}\hat{\infty} \\
\mathfrak{d} \\
\text { } \\
\hat{a}\end{array}$ & $\begin{array}{l}0 \\
0 \\
1 \\
\infty \\
\infty \\
2\end{array}$ & $\begin{array}{l}\vec{\infty} \\
\stackrel{2}{\infty} \\
m\end{array}$ & $\begin{array}{l}n \\
\infty \\
\infty \\
\infty \\
\infty \\
\infty \\
\infty\end{array}$ & $\begin{array}{l}\infty \\
2 \\
\infty \\
2 \\
0 \\
0 \\
\infty\end{array}$ & $\begin{array}{l}\tilde{n} \\
\hat{\partial} \\
\infty \\
n\end{array}$ & 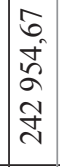 & 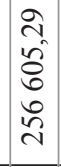 & $\begin{array}{l}\tilde{6} \\
0 \\
0 \\
0 \\
-1 \\
T\end{array}$ & $\begin{array}{l}n \\
\mathfrak{n} \\
\tilde{n} \\
\hat{2} \\
\hat{2}\end{array}$ & $\begin{array}{l}0 \\
n \\
\hat{n} \\
\hat{n} \\
\hat{N} \\
\hat{N}\end{array}$ & 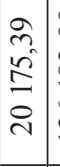 & 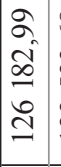 & $\begin{array}{l}\infty \\
0 \\
\tilde{n} \\
\tilde{n} \\
\tilde{\Xi} \\
\tilde{J}\end{array}$ & $\begin{array}{l}\vec{n} \\
2 \\
\tilde{J} \\
v\end{array}$ & $\begin{array}{l}\hat{\alpha} \\
\delta \\
\delta \\
n \\
\hat{2} \\
\hat{n}\end{array}$ & $\begin{array}{l}\hat{2} \\
\hat{-} \\
0 \\
\bar{\sigma} \\
\text { n. }\end{array}$ & $\begin{array}{l}8 \\
\infty \\
2 \\
\stackrel{+}{+} \\
= \\
=\end{array}$ & 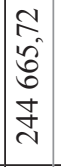 & $\begin{array}{l}\vec{n} \\
\vec{b} \\
2 \\
0 \\
\stackrel{+}{2}\end{array}$ & $\begin{array}{l}\hat{n} \\
2 \\
\hat{2}\end{array}$ \\
\hline & 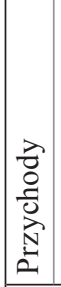 & 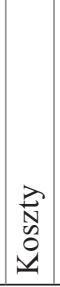 & 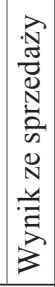 & $\mid \begin{array}{c} \\
2 \\
\frac{2}{0} \\
0 \\
\frac{0}{0} \\
\vec{N} \\
0 \\
0\end{array}$ & $\begin{array}{l}\vec{N} \\
\text { N } \\
0 \\
0 \\
\underline{1}\end{array}$ & 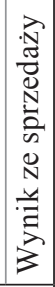 & $\mid \begin{array}{c} \\
2 \\
z \\
0 \\
0 \\
0 \\
0 \\
0 \\
0\end{array}$ & $\begin{array}{l}\overrightarrow{2} \\
\vec{N} \\
0 \\
0 \\
1\end{array}$ & 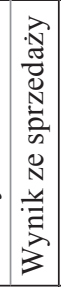 & $\mid \begin{array}{l}2 \\
0 \\
0 \\
0 \\
2 \\
0 \\
2 \\
2\end{array}$ & . & 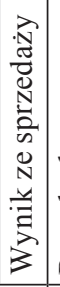 & 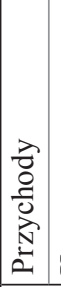 & $\begin{array}{l}\vec{D} \\
\vec{N} \\
0 \\
0 \\
\underline{v}\end{array}$ & 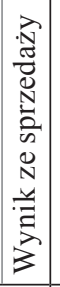 & 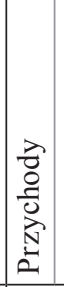 & 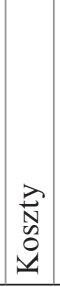 & 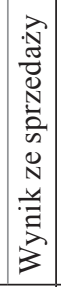 & 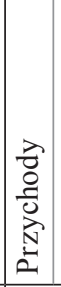 & 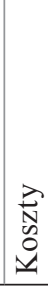 & 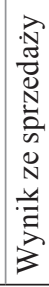 \\
\hline & & & & & 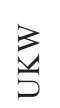 & & & & & & & & & & & & 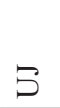 & & & & \\
\hline
\end{tabular}




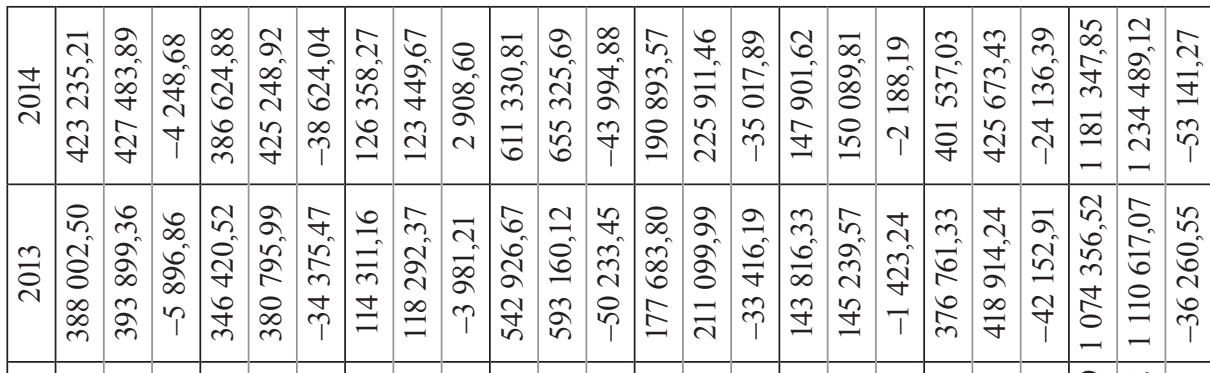

๑

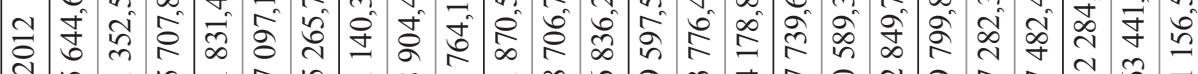

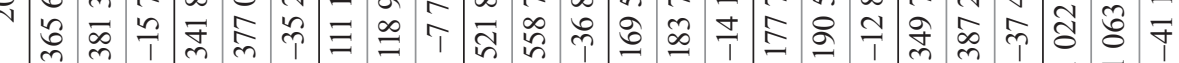

$\infty$ a

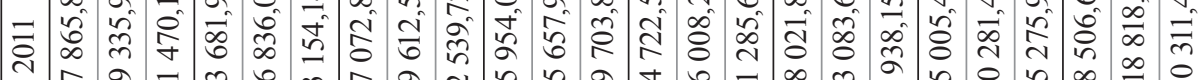

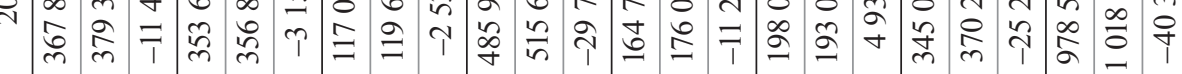

t

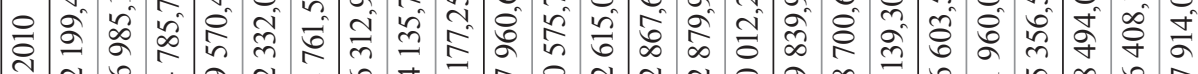
స్ల

n

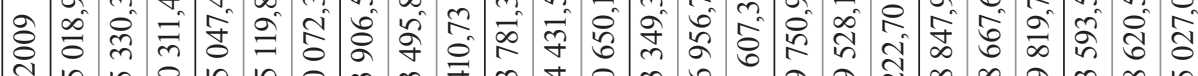

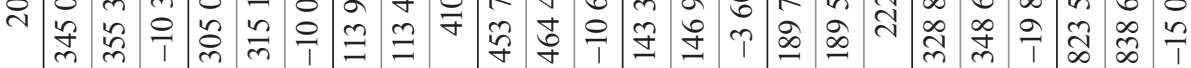

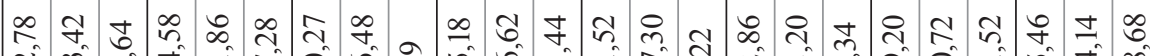

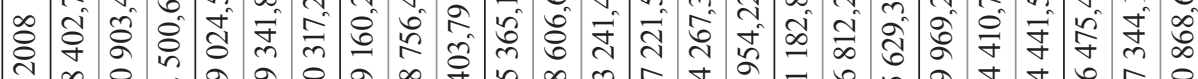

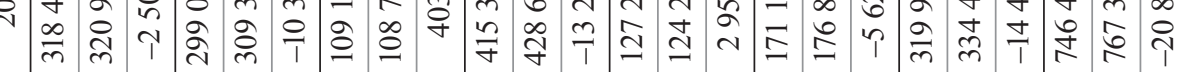

a $\infty$ 人

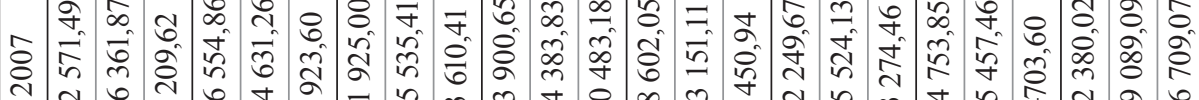

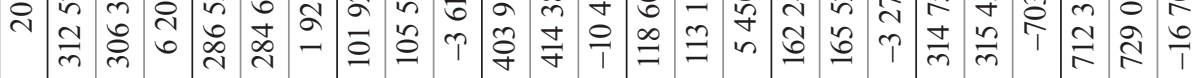

\begin{tabular}{|c|c|c|c|c|c|c|c|c|c|c|c|c|c|c|c|c|c|c|c|c|c|c|c|c|}
\hline & $\begin{array}{l}\frac{2}{0} \\
0 \\
0 \\
0 \\
0 \\
0 \\
0\end{array}$ & $\begin{array}{l}\vec{v} \\
\mathbb{v} \\
0 \\
\mathbb{v}\end{array}$ & 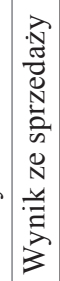 & 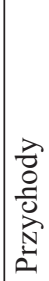 & $\begin{array}{l}\vec{N} \\
0 \\
0 \\
0 \\
0\end{array}$ & 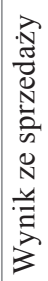 & 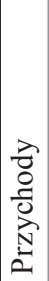 & 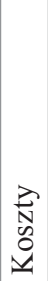 & 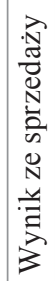 & 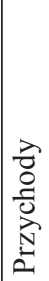 & $\begin{array}{l}\vec{\lambda} \\
N \\
0 \\
0 \\
v\end{array}$ & 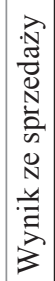 & 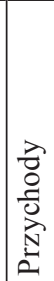 & 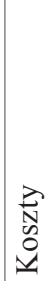 & 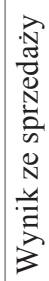 & 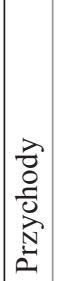 & 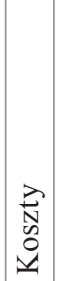 & 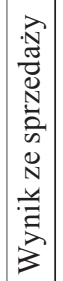 & 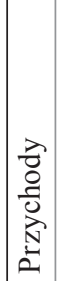 & $\begin{array}{l}\overrightarrow{2} \\
\vec{N} \\
0 \\
0 \\
\mathfrak{V}\end{array}$ & 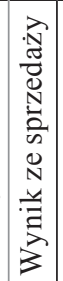 & 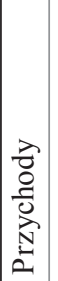 & $\begin{array}{l}\vec{\lambda} \\
0 \\
0 \\
0 \\
1\end{array}$ & 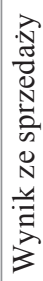 \\
\hline & & ك & & & $\sum_{j}^{3}$ & & & ᄋ & & & $\underset{⿱}{\lessgtr}$ & & & 占 & & & $\stackrel{\Omega}{\Omega}$ & & & $\sum_{S}^{V}$ & & & & \\
\hline
\end{tabular}




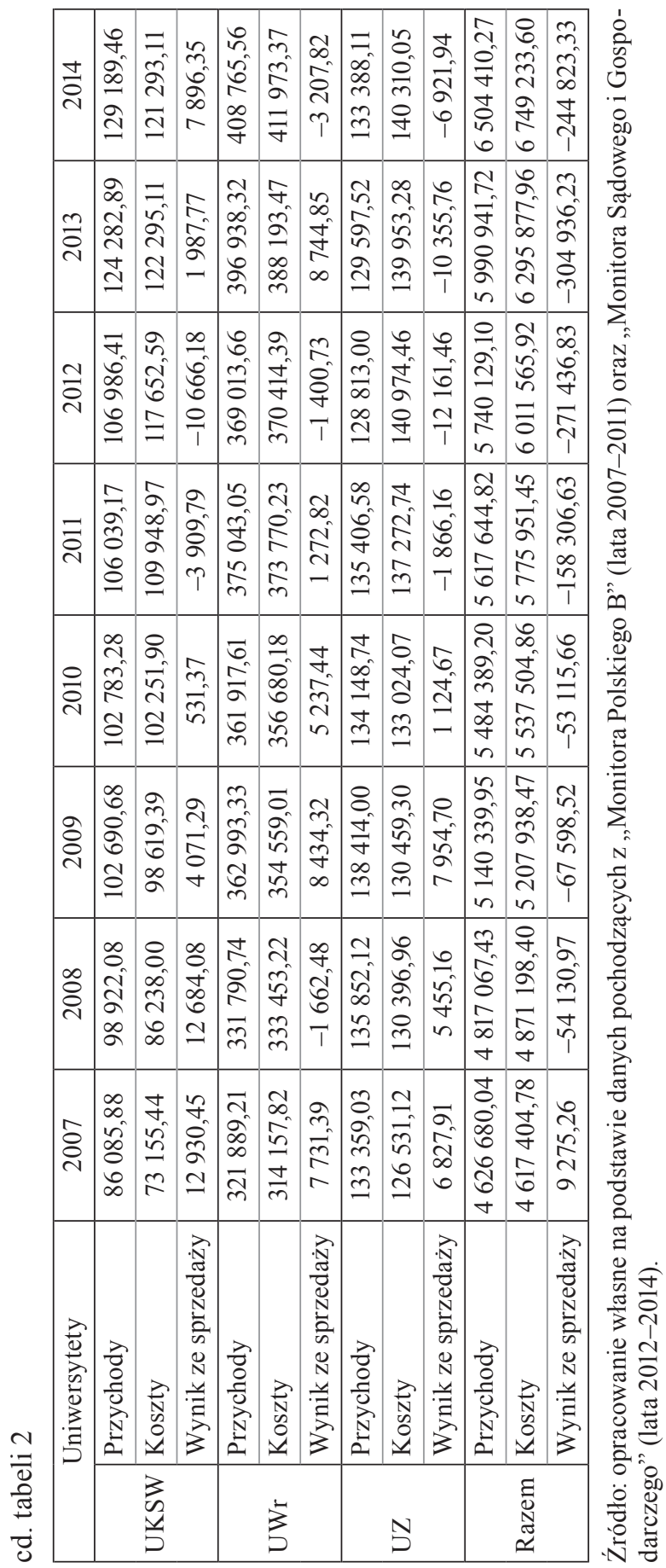


-304 936,23 mln zł w 2013 r. W 2014 r. zsumowany wynik finansowy wszystkich badanych podmiotów był również stratą, ale zmniejszył się w stosunku do roku poprzedniego o $60112,90 \mathrm{mln}$ zł.

Podsumowując, można stwierdzić, że pomimo zwiększania wartości przychodów sytuacja finansowa uniwersytetów się pogarsza. Działaniami, które muszą podejmować zarządzający uczelniami, są przede wszystkim racjonalizacja kosztów i restrukturyzacja, będąca - jak wcześniej wskazano - jednym z mechanizmów odnowy strategicznej.

W związku z tym, że plan rzeczowo-finansowy uniwersytetów (zgodnie $z$ rozporządzeniem Rady Ministrów w sprawie szczegółowych zasad gospodarki finansowej uczelni publicznych) musi się równoważyć, gdyż wszystkie planowane działania szkoły wyższej muszą mieć źródło finansowania, a ponoszenie kosztów wyższych niż zaplanowane jest naruszeniem dyscypliny finansów publicznych, podstawowe zadania w obszarach działania nie mogą wykazywać straty. Wartość ponoszonych kosztów musi być stale kontrolowana. Poziom przychodów i kosztów dotyczący podstawowych obszarów działania powinien podlegać stałej kontroli zarządzających uniwersytetami.

Zgodnie z rozporządzeniem ministra nauki i szkolnictwa wyższego dotyczącym konieczności sporządzania programów naprawczych, programy takie sporządzają uczelnie publiczne, które ustaliły stratę ogółem (analizując pięć poprzednich lat) w wysokości $25 \%$ przychodu z dotacji ubiegłorocznej. Ustalana w kolejnych latach strata ze sprzedaży (do tego obszaru należą działania sfery dydaktycznej i badawczej) powinna jednak zarządzających tymi podmiotami mobilizować do zastosowania narzędzi i działań służących do odnowy strategicznej publicznych szkół wyższych.

\section{Podsumowanie}

Zarządzający publicznymi szkołami wyższymi coraz częściej stają w obliczu trudności wynikających z braku dopasowania tych organizacji do warunków otoczenia. Utrzymywanie tego stanu może skutkować pogarszającymi się wynikami finansowymi, a to z kolei koniecznością wdrożenia nadzorowanych przez MNiSW programów naprawczych. Prowadzone w takich warunkach działania naprawcze ukierunkowane są na zmianę struktury organizacyjnej oraz ustanowienie nowych reguł i priorytetów dotyczących realizowanych w uczelniach zadań. Można przypuszczać, że w niektórych przypadkach działania te mogą zapoczątkować długotrwały i złożony proces odnowy strategicznej uczelni.

Celem opracowania było rozpoznanie niektórych przesłanek przeprowadzenia restrukturyzacji. Wykazano, że główną przesłanką wejścia organizacji na drogę 
restrukturyzacji jest pogarszający się wynik finansowy, który odsłania nieumiejętność dopasowania się uczelni do istniejących warunków otoczenia.

Analizie poddano wartości przychodów, kosztów i wyniki finansowe uniwersytetów za lata 2007-2014. Na jej podstawie sformułowano następujące wnioski:

1. W większości badanych podmiotów i okresów sprawozdawczych stwierdzono nadwyżkę przychodów nad kosztami. Ustalono również, że w żadnym $\mathrm{z}$ badanych lat nie zdarzyło się, aby wszystkie uniwersytety osiągnęły dodatni wynik finansowy. Zsumowane przychody i koszty wszystkich uniwersytetów w latach 2007-2014 dają nadwyżkę przychodów nad kosztami, z wyjątkiem 2012 r., w którym zsumowany wynik finansowy był stratą wynoszącą -27 696,94 mln zł. W większości analizowanych okresów i uniwersytetów stwierdzono wynik finansowy dodatni (wyjątkami były w 2007 r. UJ i UO, w 2008 r. UMCS, UWM, UAM i UMK, w 2009 r. UG, UMCS i UŁ, w 2010 r. UG, UMK i UZ, w 2011 r. UwB, UG, UJK, UŁ, UMK i UKSW, w 2012 r. UG, UJK, UŁ, UWM, UO, US, UMK, UW, UKSW i UZ, w 2013 r. UwB, UKW, UJK, UMCS, UMK i UZ, w 2014 r. UKW, UJK i UMCS). Najwyższe wartości ustalonej straty ogółem (ze wszystkich obszarów działania) odnotowano w przypadku Uniwersytetu Mikołaja Kopernika w 2013 r. (-16 149,56 mln zł), Uniwersytetu Kardynała Stefana Wyszyńskiego w 2012 r. (-11 650,77 mln zł) i Uniwersytetu Jana Kochanowskiego w 2013 r. (-10 511,24). Natomiast najwyższe wartości ustalonej straty ze sprzedaży (przede wszystkim z działalności dydaktycznej i badawczej) odnotowano w przypadku Uniwersytetu Warszawskiego w 2014 r. (-53 141,27 mln zł) i w 2011 r. (-40 311,45 mln zł), Uniwersytetu im. Adama Mickiewicza w 2013 r. (-50 233,45 mln zl) i w 2014 r. (-43 994,88 mln zł);

2. Na podstawie analizy badanych organizacji pod kątem konieczności wprowadzenia programu naprawczego stanowiącego narzędzie procesu restrukturyzacji nadzorowanego przez MNiSW wskazano uniwersytety, w których odnotowano najwięcej okresów sprawozdawczych z ustaloną stratą (ogółem) - 5 na 8 badanych okresów. Były to Uniwersytet Marii Curie-Skłodowskiej (zsumowana strata wynosiła -19 638,53 mln zł) i Uniwersytet Mikołaja Kopernika (-51 466,60 mln zł). W przypadku Uniwersytetu Jana Kochanowskiego odnotowano 4 na 8 badanych okresów sprawozdawczych ze stratą (jej zsumowana wartość w badanym okresie wynosiła -22 469,34 mln zł). Ponieważ zsumowane straty osiągnęły w tych podmiotach dużą wartość, należy kontrolować ich poziom, porównując ustalone wartości z dotacją podstawową otrzymywaną z MNiSW. Obserwacja taka musi być prowadzona, ponieważ przekroczenie ustalonego w przepisach prawa poziomu zsumowanej straty ogółem skutkuje koniecznością wprowadzenia nadzorowanego przez ministra nauki i szkolnictwa wyższego programu naprawczego. Uniwersytetami, w których w latach 2007-2014 nie wystąpiła strata ogółem w sprawozda- 
niach finansowych, były: Uniwersytet Śląski, Uniwersytet Jagielloński, Uniwersytet Rzeszowski i Uniwersytet Wrocławski;

3. W wartościach kosztów i przychodów uczelni ustalonych we wszystkich segmentach sprawozdania finansowego zawarte są przychody i koszty podstawowych obszarów działania i to te kategorie powinny podlegać stałej kontroli zarządzających uniwersytetami. W związku z tym, że w publicznych uczelniach, do których grupy należą badane uniwersytety, plan rzeczowo-finansowy musi się równoważyć, gdyż wszystkie planowane działania szkoły wyższej muszą mieć źródło finansowania, a ponoszenie kosztów wyższych niż zaplanowane jest naruszeniem dyscypliny finansów publicznych, podstawowe zadania w obszarach działania nie mogą wykazywać straty i poziom ponoszonych kosztów musi być stale kontrolowany. Zgodnie z rozporządzeniem ministra nauki i szkolnictwa wyższego programy naprawcze sporządzają jednostki publiczne, które ustaliły stratę ogółem z pięciu poprzednich lat w wysokości $25 \%$ przychodu z dotacji ubiegłorocznej. Ustalana w kolejnych latach strata z działalności dydaktycznej zarządzających tymi podmiotami powinna jednak mobilizować do restrukturyzacji m.in. przez obniżanie kosztów w tym kluczowym z punktu widzenia funkcjonowania uczelni obszarze działania;

4. Analizując podstawowy obszar funkcjonowania uniwersytetów, tj. działalność dydaktyczną i badawczą, ujawniono problem ponoszenia zbyt wysokich kosztów lub osiągania zbyt niskich przychodów. Bez ścisłego nadzoru nad kosztami realizowanych zadań uczelni wprowadzenie programu naprawczego może w przyszłości być konieczne w większości uniwersytetów, w sytuacji gdy w zakresie ich podstawowej działalności (głównie dydaktycznej) nie będzie równowagi między przychodami a kosztami. Pogarszająca się sytuacja finansowa uniwersytetów zmusza władze tych organizacji do niezbędnych działań korygujących, co może stanowić silną przesłankę odnowy strategicznej tych organizacji.

Dalsze badania prowadzone w tym obszarze będą zmierzać do wyznaczenia wartości referencyjnych, przy których wystąpieniu powinny zostać podjęte działania na rzecz odnowy strategicznej publicznych uczelni wyższych. Jednocześnie warto podjąć badania w kierunku rozpoznania swobody działania tych organizacji, co z kolei pozwoli ustalić odpowiednie do przeprowadzenia odnowy mechanizmy.

\section{Literatura}

Agarwal R., Helfat C.E. [2009], Strategic Renewal of Organizations, „Organization Science", vol. 20, nr 2, https://doi.org/10.1287/orsc.1090.0423.

Baden-Fuller Ch., Volberda H.W. [1997], Strategic Renewal: How Large Complex Organizations Prepare for the Future, ,International Studies of Management and Organizations", vol. 27, nr 2, https://doi.org/10.1080/00208825.1997.11656709. 
Banaszyk P., Cyfert S. [2007], Strategiczna odnowa przedsiębiorstwa, Difin, Warszawa.

Bełz G. [2012], Potencjat dostosowawczy w procesach odnowy przedsiębiorstw, „Przegląd Organizacji”, nr 11.

Ben-Menahem S.M., Kwee Z., Volberda H.W., Van Den Bosch F.A.J. [2013], Strategic Renewal Over Time: The Enabling Role of Potential Absorptive Capacity in Aligning Internal and External Rates of Change, „Long Range Planning”, vol. 46, nr 3, https:// doi.org/10.1016/j.lrp.2012.09.012.

Bratnicki M. [2000], Kompetencje przedsiębiorstwa. Od określenia kompetencji do zbudowania strategii, Agencja Wydawnicza Placet, Warszawa.

Cyfert S., Krzakiewicz K. [2015], Model procesu odnowy organizacyjnej, „Management Forum", vol. 3, nr 1, https://doi.org/10.15611/mf.2015.1.02.

Czekaj J. [2010], Konwergencja współczesnych metod zarządzania [w:] Kierunki i dylematy rozwoju nauki i praktyki zarzadzania przedsiębiorstwem, red. H. Jagoda, J. Lichtarski, Wydawnictwo Uniwersytetu Ekonomicznego we Wrocławiu, Wrocław.

De Wit B., Meyer R. [2007], Synteza strategii. Tworzenie przewagi konkurencyjnej poprzez analizowanie paradoksów, PWE, Warszawa.

Karpacz J. [2011], Determinanty odnowy strategicznej potencjału małych i średnich przedsiębiorstw. Aspekty teoretyczne i badania empiryczne, Oficyna Wydawnicza Szkoły Głównej Handlowej, Warszawa.

Karpacz J. [2012], Swoboda działania jako determinanta odnowy strategicznej przedsiębiorstwa [w:] Strategie rozwoju organizacji, red. A. Stabryła, Mfiles, Kraków.

„Monitor Polski B” [2008-2012], Sprawozdania finansowe za lata 2007-2011, www. monitorb.pl.

„Monitor Sądowy i Gospodarczy” [2013-2015], Sprawozdania finansowe za lata 20122014, https://mojepanstwo.pl/krs/msig.

Nogalski B., Karpacz J., Wójcik-Karpacz A. [2015], Spojrzenie na odnowę strategiczna z punktu widzenia długowieczności organizacji, „Management Forum”, vol. 3, nr 1, https://doi.org/10.15611/mf.2015.1.13.

Quinn J.B. [1978], Strategic Change: Logical Incrementalism, „Sloan Management Review", vol. 20, nr 1.

Rozporządzenie Ministra Nauki i Szkolnictwa Wyższego z dnia 5 października 2011 r. w sprawie zakresu i trybu realizacji programu naprawczego prowadzącego do uzyskania równowagi finansowej uczelni publicznej, Dz.U. nr 243 poz. 1446.

Sharma P., Chrisman J.J. [1999], Toward a Reconciliation of the Definitional Issues in the Field of Corporate Entrepreneurship, „Entrepreneurship Theory and Practice”, vol. 23, nr 3 .

Stabryła A. [2010], Wybrane problemy metodologii badań w projektowaniu rozwoju przedsiębiorstwa [w:] Innowacje w zarzadzaniu przedsiębiorstwem oraz instytucjami sektora publicznego, red. H. Bieniok, T. Kraśnicka, Wydawnictwo Akademii Ekonomicznej w Katowicach, Katowice.

Ustawa z dnia 29 września 1994 r. o rachunkowości, Dz.U. nr 121 poz. 591 z późn. zm.

Ustawa z dnia 27 lipca 2005 r. Prawo o szkolnictwie wyższym, Dz.U. nr 164 poz. 1365 z późn. zm. 


\section{The Rationale for Restructuring as a Mechanism of the Strategic Renewal of Public Higher Education Institutions}

(Abstract)

One of the most pressing issues facing contemporary public higher education institutions is their need to adjust to the continuously changing conditions of the surrounding environment. Lack of integration of those institutions with the environment reduces their economic effectiveness. In the light of current legal regulations, this may eventually lead to their liquidation. The aim of this work is twofold: to identify the rationale for restructuring as a mechanism of the strategic renewal of public higher education institutions, and to present the reasoning to the authorities of those institutions. The article analyses sales results, which are established by examining the revenues and costs of academic and research activity as well as separate business activity. The article also looks at universities' overall financial results. The circumstances for developing a recovery programme that will lead to financial balance in public higher education institutions are identified. Universities in Poland were the subject of the research, which covered their total financial and sales results stated in financial statements for the years 2007-2014. Analysis of the fundamental area of the universities' functioning - academics and research - reveals that costs are too high and revenues too low. Without strict supervision of costs, implementation of a recovery programme may be executed in the majority of public higher education institutions in the future. This may be the result of the situation when the fundamental activity of those institutions (didactic activity mainly) is not balanced between revenues and expenses. The worsening financial situation of universities is forcing managing authorities to undertake corrective measures. Any further actions within this area will seek to designate reference values, which should be followed by actions to the benefit of a strategic renewal of public higher education institutions.

Keywords: public higher education institutions, strategic renewal, restructuring, recovery programme. 